\title{
Compatibility Tests between Genetic Linkage Groups in a Strain of Staphylococcus aureus
}

\author{
By KATHRINE DORNBUSCH \\ Institute of Medical Microbiology, University of Uppsala, Uppsala, Sweden
}

(Received 8 May 1972; revised 23 October 1972)

\begin{abstract}
SUMMARY
Two variants of strain AC 17855 of Staphylococcus aureus, each carrying a welldefined penicillinase plasmid, were used in transduction to test the compatibility of two suggested plasmids in a wild strain DU 49I6 of Staphylococcus aureus. One of the plasmids in the wild strain, which was responsible for methicillin resistance and enterotoxin B production, was compatible with penicillinase plasmids of compatibility group I, whereas the other, responsible for penicillinase production, was not. Since the penicillinase activity in the wild strain was stimulated after addition of antipenicillinase of serotype $\mathrm{A}$, it was concluded to be an $\alpha$-plasmid.
\end{abstract}

\section{INTRODUCTION}

The chromosomal and extrachromosomal nature of some genetic characters in Staphylococcus aureus has been described (Collins \& Roy, 1963; Richmond, I968; Novick, I969). Both chromosomal and plasmid-bound genes for production of penicillinase occur (Asheshov, 1969). Among the penicillinase plasmids, eleven different types have been defined by Richmond (I968) and divided into two compatibility groups, com I and com II (Novick \& Richmond, I965). Plasmids which can co-exist in a single bacterium, e.g. an $\alpha$-plasmid (com I) and a $\beta$-plasmid (com II), are said to be compatible. Plasmids which cannot co-exist in a single cell, e.g. an $\alpha$-plasmid and a $\gamma$-plasmid (both com I), or two $\alpha$ plasmids, are said to be incompatible. Novick \& Richmond (I965) suggested that this compatibility phenomenon can be explained by an attachment site hypothesis, plasmids of the same compatibility group competing for the same cellular attachment site, whereas plasmids of different compatibility groups each have their own attachment site. Other types of plasmids fully compatible with the penicillinase plasmids are those responsible for resistance to tetracycline (May, Houghton \& Perret, 1964) and to chloramphenicol (Chabbert, Baudens \& Gerbaud, I964).

Resistance of Staphylococcus aureus to benzylpenicillin usually results from the production of an inducible penicillinase (a lactamase). The penicillinase genes are clustered and comprise a structural gene for penicillinase production (pen), two regulatory genes $\left(i\right.$ and $\left.i_{2}\right)$, which specify the cytoplasmic penicillinase repressor and the promotor gene ( $p r)$ (Richmond, 1966; Richmond, 1967). An $i^{-}$mutation results in constitutive production of the enzyme.

Three immunological variants of the enzyme have been identified of A-, B- or C-serotypes (Richmond, 1968). Anti-A penicillinase has been produced by Richmond and the antigenantibody reaction results in a stimulation of the enzyme activity (Richmond, I963).

In this investigation, attempts are made to describe more fully some possible plasmids in a strain of Staphylococcus aureus (Dornbusch, Hallander \& Löfquist, I969; Dornbusch 
\& Hallander, 1973). The methods used are compatibility tests achieved by transducing defined plasmids into the strain and examination of the penicillinase activity of the strain after addition of antiserum.

\section{METHODS}

Strains of Staphylococcus aureus. The following two different variants of strain AC I 7855 were kindly supplied by Dr E. Asheshov, Colindale, London (Table I). This strain is naturally resistant to both arsenate and cadmium ions and the genes controlling these resistances are chromosomal (Dyke, Parker \& Richmond, 1970).

(i) AC I7855 ( $\alpha i^{-}$pen $^{+} \gamma$ ero-r $)$ : this variant carries a recombinant $\alpha$-plasmid constitutive for penicillinase $\left(i^{-}\right.$pen $\left.^{+}\right)$with the erythromycin resistance (ero-r) derived from a $\gamma$-plasmid. (ii) AC $17855\left(\gamma i^{-}\right.$pen $^{+} H g$-r ero-r $)$ : this variant carries a $\gamma$-plasmid responsible for constitutive penicillinase production $\left(i^{-}\right.$pen $\left.{ }^{+}\right)$and resistance to $\mathrm{Hg}^{2+}(\mathrm{Hg}-r)$ and erythromycin (ero-r).

Both variants were used as donors in the transduction experiments. The recipient strain, DU 4916 pen $^{+}$met-r, produces penicillinase inducibly $\left(i^{+}\right)$, is toxinogenic and resistant to methicillin (met-r) and metallic ions ( $\mathrm{Hg}-\mathrm{r} \mathrm{Cd}-\mathrm{r})$ (Dornbusch \& Hallander, I973).

Media. Nutrient agar (Difco, Detroit, Michigan, U.S.A.) was used in plates with erythromycin (Io $\mu \mathrm{g} / \mathrm{ml}$ ). For bacterial broth cultures Brain Heart Infusion broth (Difco) was used.

Sensitivity tests. Resistance to benzylpenicillin, methicillin and erythromycin was determined in a plate dilution test (Barber \& Waterworth, 1964). The minimal inhibitory concentration (m.i.c.) is the lowest concentration which inhibits growth completely. The disc diffusion test (Ericsson, I960) was used for antibiograms.

Assay of enzymes and toxins. Assays of free coagulase and production of enterotoxin B were determined as described by Hallander (1965).

Assay of penicillinase. Penicillinase production by single colonies could be detected by their reaction on starch agar plates according to Dyke, Jevons \& Parker (1966). Without the inducer methicillin in the agar, inducible and constitutive enzyme production could be distinguished.

Serological typing of penicillinase. This was according to Richmond (1963), and the author also kindly supplied the antiserum A. Penicillinase production was induced overnight at $37^{\circ} \mathrm{C}$ in broth containing $0.5 \mu \mathrm{g}$ methicillin $/ \mathrm{ml}$. After centrifugation the activity of the exoenzyme in the broth was measured micro-iodometrically (Novick, 1962) in the presence of increasing quantities of antibody.

Phage typing. The method of Blair \& Williams (196I) using a standard set of typing phages and the phage 88 was used.

Preparation of typing phage 29 . This was propagated at $30^{\circ} \mathrm{C}$ on the various donor strains by the soft-agar overlay method of Swanstrom \& Adams (I95I). Bacteria were removed by Millipore filtration. Phage titres were determined as plaque-forming units (p.f.u.)/ml and were in the range of $10^{8}$ to $10^{9} / \mathrm{ml}$.

Transduction experiments. Typing phage 29 was used (Asheshov, $1966 b$ ). The multiplicities of infection varied between 0.8 to $\mathrm{I} \cdot 4$ and erythromycin $(\mathrm{I} 0 \mu \mathrm{g} / \mathrm{ml})$ was used for selection. Plates were incubated for $48 \mathrm{~h}$ at $37^{\circ} \mathrm{C}$. Controls, comprising sterility tests of the phage lysate and tests for back mutation in the absence of transducing phage, were performed in each experiment.

Loss of erythromycin resistance after growth at $44{ }^{\circ} \mathrm{C}$. This was described by Asheshov (I966a). 


\section{RESULTS}

Phenotypes of the donor and recipient strains (Table $\mathrm{I}$ ). The two variants of strain AC 17855 were sensitive to most antibiotics and non-toxinogenic. They differed from each other in that the $\gamma$-plasmid conferred higher resistance to metallic ions to the strain. Strain DU 4916 $i^{+}$pen ${ }^{+}$met-r has been described in more detail by Dornbusch et al. (1969) and Dornbusch \& Hallander (1973).

\section{Compatibility tests (Table 2)}

I. In a first series of experiments, the $\alpha$-plasmid was transduced into the recipient in the cross DU49I6 ( $i^{+}$pen $n^{+}$ero-s) met-r $\times$phage 29/ACI7855 $\left(\alpha i^{-}\right.$pen ${ }^{+} . \gamma$ ero- $\left.r\right)$ met-s at the multiplicity of infection 0.8 . Resistant transductants were obtained at a frequency of $4.7 \times 10^{-7}$. Nine out of $185(4.9 \%)$ transductants were inducible for penicillinase $\left(i^{+}\right.$pen $\left.^{+}\right)$ on starch agar plates but were as resistant to $\mathrm{Hg}^{2+}$ and $\mathrm{Cd}^{2+}$ as the recipient. The remaining I 76 transductants were constitutive $\left(i^{-}\right.$pen $\left.^{+}\right)$for penicillinase and were more sensitive to $\mathrm{Hg}^{2+}$ and $\mathrm{Cd}^{2+}$. The phage type of the transductants were the same as the recipient. Of Ioo transductants tested (either $i^{-}$pen ${ }^{+}$or $i^{+} p e n^{+}$) all were methicillin resistant and produced enterotoxin B.

2. In a second series of experiments, the $\gamma$-plasmid was transduced in the cross DU $49 \mathrm{I} 6$ $\left(i^{+}\right.$pen ${ }^{+}$ero-s) met-r $\times$phage $29 / \mathrm{AC} I 7855\left(\gamma i^{-}\right.$pen $^{+} H g-r$ ero-r $)$ met-s. The multiplicity of infection was $\mathrm{I} \cdot 0$.

In one experiment erythromycin-resistant transductants were obtained at a frequency of $7.0 \times 10^{-8}$. Eighteen of $50(36 \%)$ transductants tested were inducible for penicillinase $\left(i^{+}\right.$pen $\left.n^{+}\right)$, the remainder being constitutive $\left(i^{-}\right.$pen $\left.n^{+}\right)$. The phage type was the same as the recipient, and the transductants were still methicillin resistant and produced enterotoxin $B$. In another experiment, two colonies were obtained (a transduction frequency of $2 \cdot 9 \times 10^{-9}$ ), which were inducible for penicillinase $\left(i^{+} p e n^{+}\right)$, methicillin sensitive and did not produce enterotoxin B. Like the recipient they were lysed by phages 29 and 88 . The frequency of back mutation of the recipient to ero-r in the absence of transducing phage was less than $1 \mathrm{I}^{-10}$ in all controls.

Loss of erythromycin resistance (Table 3 ). Attempts were made to eliminate the erythromycin resistance of the transductants by growth at $44^{\circ} \mathrm{C}$. Sensitive colonies were then tested for penicillinase production, methicillin resistance, enterotoxin $\mathrm{B}$ production and heavy metal ion resistance. Erythromycin resistance and penicillinase production were lost simultaneously by approximately $2 \%$ of donor bacteria after treatment. From cross I four $i^{-}$pen ${ }^{+}$transductants and two $i^{+}$pen $n^{+}$transductants were tested. Loss of erythromycin resistance was obtained at different frequencies $(0.5$ to $6.6 \%$ ) from these transductants. Of the 160 erythromycin-sensitive colonies obtained, all were penicillinase negative and produced enterotoxin B. Three out of the $\mathrm{I} 60(\mathrm{I} \cdot 9 \%)$, however, lost their methicillin resistance. From cross 2, two $i^{-}$pen ${ }^{+}$and two $i^{+}$pen $n^{+}$transductants were tested 0.2 to $0.8 \%$ of colonies being erythromycin sensitive. They were all penicillinase negative and sensitive to $\mathrm{Hg}^{2+}$ and $\mathrm{Cd}^{2+}$.

Among some of the erythromycin-sensitive transductants obtained after treatment at $44{ }^{\circ} \mathrm{C}$ there was a change in the phage typing pattern from $29 / 53 / 88$ to $29 / 52 / 79 / 6 / 47 / 53 / 54 /$ 77/8I/88. Asheshov \& Jevons (I963) found that growth at elevated temperature caused a transient phenotypic change in the phage-sensitivity of certain strains of Staphylococcus aureus.

Stimulation of the enzyme activity after addition of antipenicillinase. Strain DU49I6 was 
Table I. Phenotypes of the donors of strain AC 17855 and the recipient of strain DU $49 \mathrm{I} 6$

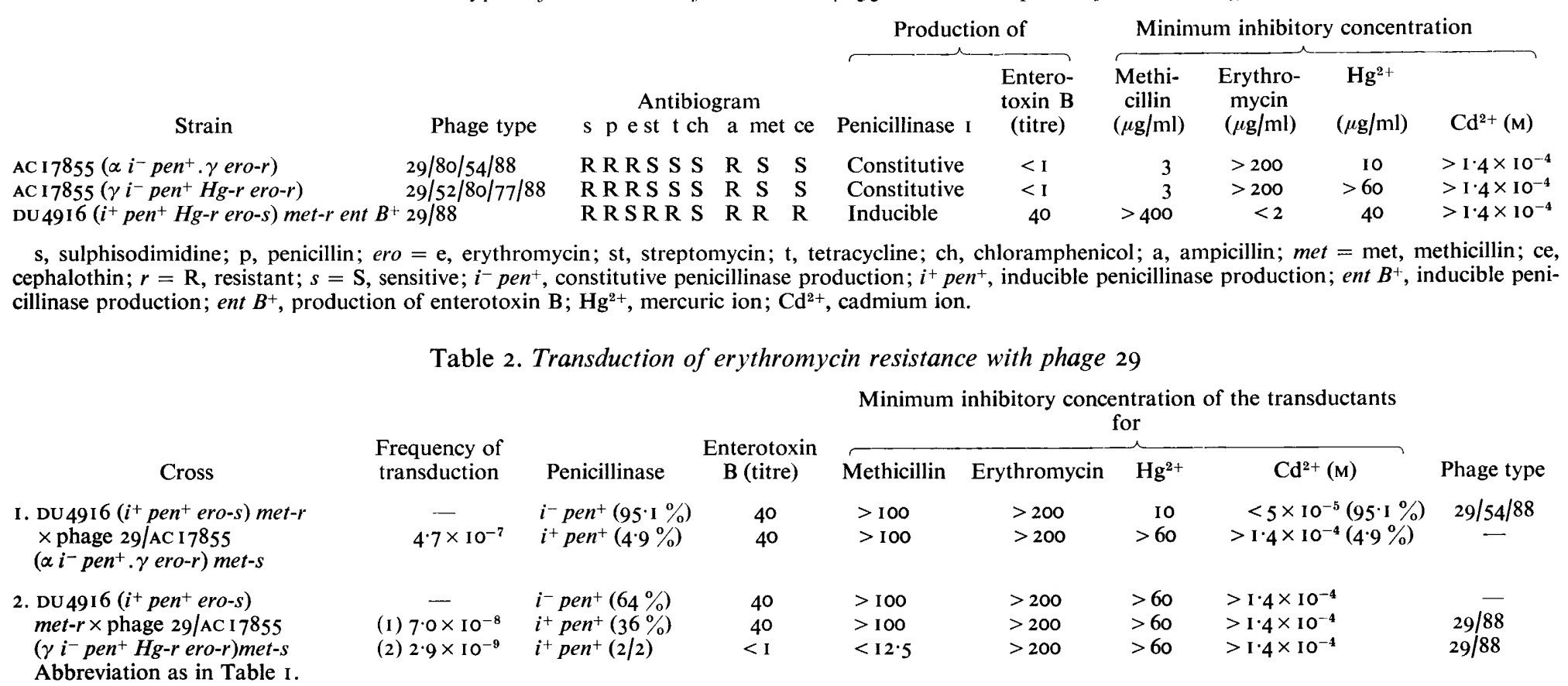


Table 3. Change of phenotype of erythromycin-resistant, penicillinase-producing transductants after growth at $44^{\circ} \mathrm{C}$

$\begin{array}{cc}\text { Cross* }^{*} & \begin{array}{r}\text { Simultaneous loss of } \\ \text { ero-r } \text { and pen }\end{array} \\ 1 & 0.5-6.6 \\ 2 & 0.2-0.8\end{array}$

\begin{tabular}{|c|c|c|c|}
\hline$H g-r$ & $C d-r$ & met-r & ent $B^{+}$ \\
\hline $0.2-0.8$ & $0.2-0.8$ & $I \cdot 9 \%(3 / 160)$ & - \\
\hline
\end{tabular}

Abbreviations as in Table I.

* As in Table 2.

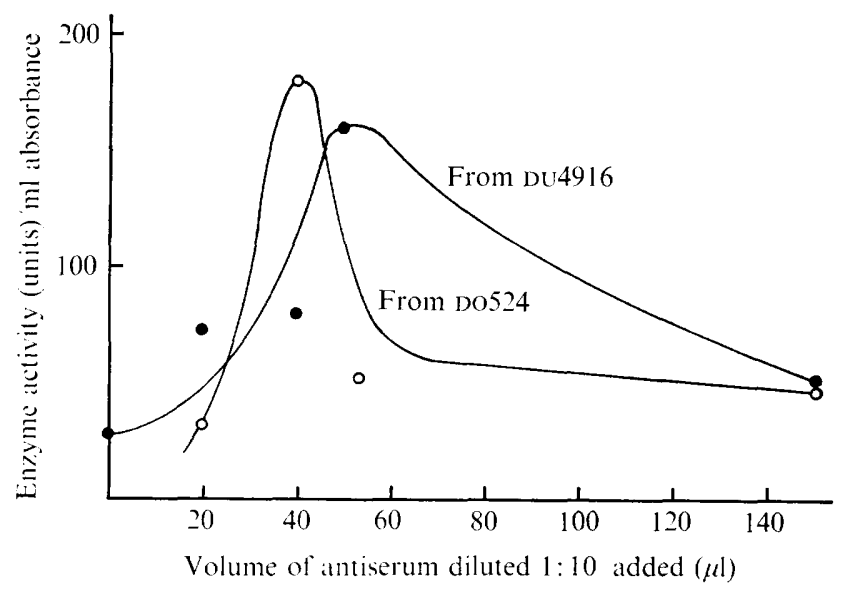

Fig. I. Stimulation of penicillinase activity by the addition of antipenicillinase of serotype A measured in micro-iodometric assays. One penicillinase unit is defined as the amount of enzyme that catalyses the hydrolysis of I $\mu$ mol benzylpenicillin during I h at $25^{\circ} \mathrm{C}$ at $\mathrm{pH} 5 \cdot 8$. For determinations of enzyme activities a calibration against known amounts of enzyme (Calbiochem $\mathrm{Co}$, La Jolla, California, U.S.A., lot no. 80046) was performed. Absorbance: reduction of iodide as measured continuously in a Beckman DB spectrophotometer at $620 \mathrm{~nm}$.

induced to produce penicillinase, the exoenzyme was titrated with increasing quantities of antibody (constant antigen titration) and the enzyme activity of the total preparation measured micro-iodometrically (Fig. 1). The activity of the preparation increased with increasing quantities of antiserum. Strain Do 524 which produces A-type penicillinase (Dyke, Jevons \& Parker, I966) was included as a positive control.

\section{DISCUSSION}

The plasmid for inducible penicillinase production in strain DU 49I6 was eliminated by an incoming $\alpha$-or $\gamma$-plasmid. This was illustrated in the two transduction crosses (Table 2 ). In the first cross $95 \%$ of the erythromycin-resistant transductants were constitutive for penicillinase $\left(i^{-}\right.$pen $\left.{ }^{+}\right)$and more sensitive to $\mathrm{Hg}^{2+}$ and $\mathrm{Cd}^{2+}$. All those markers characterized the incoming $\alpha$-plasmid. The resident penicillinase plasmid must have been eliminated, since $i^{+}$pen $^{+} / i^{-}$pen $n^{+}$plasmid diploid bacteria are still inducible for the enzyme (Richmond, I968). The remaining $5 \%$ erythromycin-resistant transductants were inducible for penicillinase and resistant to heavy metal ions. The $\alpha$-plasmid, itself a recombinant, must in this case have been deleted and only the ero-r marker have been transferred and recombined 
with the resident penicillinase plasmid. In the other cross, the $\gamma$-plasmid could be transduced into the recipient to the detriment of the resident inducible penicillinase plasmid. This was obvious as $64 \%$ of the transductants tested produced the enzyme constitutively. In the two crosses, with the exception of two transductants, all were resistant to methicillin and produced enterotoxin B. In the met-s transductants the incoming $\gamma$-plasmid or the ero-r marker may have eliminated the met-r ent $B^{+}$(enterotoxin B) markers, whereas the resident penicillinase plasmid was not eliminated since the transductants produced the enzyme inducibly (Asheshov, 1966 $b$; Richmond, 1968). Another explanation may be a spontaneous loss of the met-r ent $B^{+}$markers in parallel with transduction of the ero-r marker.

It can be concluded that the resident plasmid in strain DU 49r6, which was isolated from an infected burn, and capable of inducible penicillinase production belongs to compatibility group I, since it was incompatible with the $\alpha$ - and $\gamma$-plasmids in transduction experiments. In addition it seems to be an $\alpha$-plasmid itself, since its enzymatic activity could be increased fivefold by addition of antipenicillinase of serotype A (Fig. I). This is in agreement with the result of others (M. R. Pollock, unpublished results; Richmond, I963). The most common penicillinase plasmid among hospital strains is the $\alpha$-plasmid (Dyke \& Richmond, 1967; Richmond, I968; Dyke, Parker \& Richmond, 1970), whereas the $\gamma$-plasmid has only been isolated once (Richmond, 1968). The $\beta$-plasmid has been isolated from hospital strains belonging to phage group II (Richmond, I968). The genes responsible for methicillin resistance and enterotoxin $\mathrm{B}$ production seemed to be compatible with the incoming genes, since the transductants were still methicillin resistant and toxinogenic. In one transduction experiment, however, the genes seemed to be eliminated by the incoming $\gamma$-plasmid. This did not seem to be a very common phenomenon. Treatment of the ero-r transductants from the two crosses at $44{ }^{\circ} \mathrm{C}$ should result in the loss of the transduced plasmids (Asheshov, I $966 a$ ). The results clearly illustrate this phenomenon, since all erythromycin-sensitive colonies were also penicillinase negative (Table 3 ). In three cases methicillin resistance was co-eliminated. Loss of methicillin resistance after growth at $43{ }^{\circ} \mathrm{C}$ has recently been reported as a consequence of altered surface properties of the cell (Al Salihy \& James, 1972) which supports the suggestion that the genes for methicillin resistance are plasmid-bound.

\section{REFERENCES}

Al Salihy, S. M. \& James, A. M. (I972). Loss of methicillin-resistance from resistant strains of Staphylococcus aureus. Lancet i, 33 I-332.

Asheshov, E. H. (I $966 a$ ). Loss of antibiotic resistance in Staphylococcus aureus resulting from growth at high temperature. Journal of General Microbiology 42, 403-4I0.

Asheshov, E. H. (I $966 b$ ). Chromosomal location of the genetic elements controlling penicillinase production in a strain of Staphylococcus aureus. Nature, London 210, 804-806.

Asheshov, E. H. (I969). The genetics of penicillinase production in Staphylococcus aureus strain PS 80. Journal of General Microbiology 59, 289-30I.

Asheshov, E. H. \& Jevons, M. P. (I963). The effect of heat on the ability of a host strain to support the growth of staphylococcus phage. Journal of General Microbiology 3r, 97-107.

Barber, M. \& Waterworth, B. P. (1964). Penicillinase-resistant penicillins and cephalosporins. British Medical Journal ii, 344-349.

Blair, J. E. \& Williams, R. E. O. (I96I). Phage typing of staphylococci. Bulletin of the World Health Organization 24, 77I-784.

Chabbert, Y. A., Baudens, J. G. \& Gerbaud, G. R. (1964). Variation sous l'influence de l'acriflavine et transduction de la résistance à la kanamycin et au chloramphenicol chez les staphylocoques. Annales l'Institut Pasteur 107, 678-690.

Collins, A. M. \& Roy, T. E. (1963). Transduction of chloramphenicol and novobiocin resistance in staphylococci. Canadian Journal of Microbiology 9, 54I-547. 
Dornbusch, K. \& Hallander, H. O. (1973). Transduction of penicillinase production and methicillin resistance-enterotoxin B production to strains of Staphylococcus aureus. Journal of General Microbiology 76, I-II.

Dornbusch, K., Hallander, H. O. \& LöfQvist, F. (1969). Extrachromosomal control of methicillin resistance and toxin production in Staphylococcus aureus. Journal of Bacteriology 98, 35I-358.

Dyke, K. G. H., Jevons, M. P. \& PARker, M. T. (I966). Penicillinase production and intrinsic resistance to penicillins in Staphylococcus aureus. Lancet $\mathrm{i}, 835-838$.

Dyke, K. G. H., Parker, M. T. \& Richmond, M. H. (1970). Penicillinase production and metal-ion resistance in Staphylococcus aureus cultures, isolated from hospital patients. Journal of Medical Microbiology 3, 125-1 36.

Dyke, K. G. H. \& Richmond, M. H. (1967). Occurrence of various types of penicillinase plasmids among "hospital" staphylococci. Journal of Clinical Pathology 20, 75-79.

ERICSSON, H. (1960). Rational use of antibiotics in hospitals. Scandinavian Journal of Clinical and Laboratory Investigation 12, Suppl. 50.

Hallander, H. O. (1965). Production of large quantities of enterotoxin B and other staphylococcal toxins on solid media. Acta pathologica et microbiologica scandinavica $\mathbf{6}_{3}, \mathbf{2 9 9 - 3 0 5}$.

May, J. M., Houghton, R. H. \& Perret, C. J. (1964). The effect of growht at elevated temperatures on some heritable properties of Staphylococcus aureus. Journal of General Microbiology 37, I 57-169.

Novick, R. P. (I962). Micro-iodometric assay for penicillinase. Biochemical Journal 83, 236-240.

Novick, R. P. (I 969). Extrachromosomal inheritance in bacteria. Bacteriological Reviews 332 I0-263.

Novick, R. P. \& Richmond, M. H. (1965). Nature and interactions of the genetic elements governing penicillinase synthesis in Staphylococcus aureus. Journal of Bacteriology 9o, 467-480.

Richmond, M. H. (1963). Purification and properties of the exopenicillinase from Staphylococcus aureus. Biochemical Journal 88, 452-459.

RICHMOND, M. H. (1966). The genetic constitution of certain penicillinase micromutants in Staphylococcus aureus. Journal of General Microbiology 45, 5I-60.

Richmond, M. H. (1967). A second regulatory region involved in penicillinase synthesis in Staphylococcus aureus. Journal of Molecular Biology 26, 357-360.

Richmond, M. H. (1968). The plasmids of Staphylococcus aureus and their relation to other extrachromosomal elements in bacteria. In Advances in Microbial Physiology, vol. 2, pp. 43-88. Edited by A. H. Rose and J. F. Wilkinson. New York and London: Academic Press.

Swanstrom, M. \& Adams, M. H. (I95I). Method for production of high titer phage stocks. Proceedings of the Society for Experimental Biology and Medicine 78, 372-375. 